\title{
Effect of human urine as fertilizer on crop production
}

\author{
HK Upreti*, P Shrestha ${ }^{* *}$, and P Paudel ${ }^{* *}$
}

\begin{abstract}
Nutrient cycling in the soil-plant ecosystem is an essential component of sustainable agriculture. Human excreta though have high nutrient value is being neglected and simply dumped as waste. Out of the human excreta, urine has high nitrogenous fertilizer value than feces. Hence by separating urine in ECOSAN toilet, it can be of great use in fulfilling the fertilizer demand of the country. The main objective of this study is to assess the effect of human urine on crop yield and to find out the appropriate urine dose and time of application to different crops. The study shows that urine can act as effective as a chemical fertilizer and can be used as an efficient source of plant nutrients. In general, 2-3 splits urine application in addition with phosphorus and potash fertilizer gave the comparable result with that of chemical fertilizer. Though there is no statistical difference in production of the crops, the average yield was found to be higher in the application of chemical fertilizer in all crops except in wheat. From the study, it can be concluded that any crops can be grown using urine as a fertilizer without significant reduction in the yield if nutrient losses during handling could minimize. The study recommends the further study in a long-term urine application trial to verify the obtained result and also to observe the effect of urine on soil properties and plant health as well as on the efficacy of urine along with compost in crop production.
\end{abstract}

Key words: Crop, plants nutrients, urine, yield

\section{Introduction}

Nutrient cycling in the soil-plant ecosystem is an essential component of sustainable agriculture. Nutrient removed from the soil by crops should be restored to retain the soil fertility. The use of animal and crop waste in the form of farm yard manure (FYM) or compost is common practices in majority of the farm community. But the importance of the plant nutrients content in human waste has never been realized as an alternative source of fertilizer for crop production. The introduction of ecological sanitation (ECOSAN) toilets in Nepal has created opportunities for safer sanitation and recycling of human waste as fertilizer.

\footnotetext{
* Agriculture Botany Division, NARC. hari_upreti@yahoo.com

${ }^{* *}$ Environment and Public Health Organization, Kathmandu, Nepal
} 
Human excreta have been used as a fertilizer since long back. Out of the human excreta i.e. faces and urine, urine has high nitrogenous fertilizer value than feces. Urine contains up to 0.9:0.12:0.26 \% of N, P and $\mathrm{K}$ respectively (Vinneras et al 2004). Urine is quick acting fertilizer rich in nitrogen can be apply directly to the soil as it is entirely sterile products and the health risk from the use of urine has found to be negligible (Hoglund et. al. 2000) where as feces matter act slow and contains organic matter along with other plant nutrients. Both urine and feces material well supplements each other to matches the needs crop plant. However, feces material should be sanitized before use, since it may contain high concentrations of pathogens and unrecompensed particles.

Nepalese soil is very much deficient in Nitrogen content, low to medium in Phosphorus content and medium to rich in potassium content (Joshi, 2002). Hence Nitrogenous fertilizer is the necessary supplement in soil in order to increase the productivity of the country and about 15458 ton of chemical fertilizer (mostly urea) is imported in Nepal in a fiscal year 2008/09 (MoAC, 2009). It is estimated that an adult excretes about 550 liters of urine per year (Esrey et al, 1998). 550 liters of urine is calculated to have $4.0 \mathrm{~kg}$ of nitrogen, $365 \mathrm{~g}$ of phosphorus and $1 \mathrm{~kg}$ of potash (Vinneras and Jonson 2002). Nepal total population in a year 2009 is $27,504,280$. If only $50 \%$ of total population of Nepal starts to collect urine, it equivalent about 120:11:23 thousand ton urea, triple super phosphate and Muriate of potash respectively which can totally fulfill the demand of chemical fertilizer in Nepal and can also save the foreign currency needed to import these fertilizer.

Experiment in other countries has proved that nutrients in urine are easily accessible to plants and as effective as chemical fertilizers. In Nepal very little research has been carried out on the use and effect of human urine as a source of plant nutrient. Hence, this experiment was conducted to study and gather more knowledge on the efficacy of human urine on crop yield.

\section{Methodology}

The research comprised of following five treatments:

1. Full dose of urine at basal only

2. Chemical only but nitrogen at ( 2 split)

3. Full dose of urine and PK at basal

4. Urine at (2 split) and PK at basal

5. Urine at (3 split) and PK at basal

Treatment one was modified to apply in 3 split as per the results of first crop (potato) research. Similarly, the dose of urine applied was increased by $20 \%$ to compensate the nutrient losses during storage and handling. The treatment was laid out in Randomized Complete Block Design (RCBD) with four replications of each treatment. The amount of urine and fertilizer was calculated on the basis of recommended dose of each crop. The 
fertilizers used were urea $(46 \% \mathrm{~N})$, single super phosphate $\left(16 \% \mathrm{P}_{2} \mathrm{O}_{5}\right)$ and Muriate of potash $\left(60 \% \mathrm{~K}_{2} \mathrm{O}\right)$. The nutrient status of urine was $0.8,0.025$ and $0.08 \%$ NPK respectively. The detail of methodologies is given in (Table 1).

Table 1. Methodology adopted for the research crops

\begin{tabular}{lccccc}
\hline \multicolumn{1}{c}{ Crop } & Year & $\begin{array}{c}\text { Plot size } \\
(\text { Sq. m) }\end{array}$ & $\begin{array}{c}\text { Spacing } \\
(\mathbf{c m} \times \mathbf{~ c m})\end{array}$ & $\begin{array}{c}\text { Fertilizer dose } \\
(\mathbf{N}: \text { P:K kg/ha) }\end{array}$ & Variety \\
\hline Potato & 2004 & 8.5 & $75 \times 25$ & $150: 100: 30$ & Kufri Jyoti \\
Potato & 2005 & 10.5 & $75 \times 25$ & $150: 100: 30$ & Janak Dev \\
Rice & $2004-5$ & 9.0 & $20 \times 15$ & $80: 40: 30$ & Khumal-11 \\
Radish & $2004-5$ & 1.0 & $15 \times 10$ & $100: 60: 80$ & Pyuthane Rato \\
Onion & 2005 & 1.0 & $15 \times 10$ & $100: 60: 40$ & Red Criol \\
Wheat & $2005-6$ & 10.5 & $25 \times$ Continuous & $80: 40: 30$ & WK 1204 \\
\hline
\end{tabular}

The urine applied at 25-30 and 50-60 days after planting as foliar application was diluted with water in the ratio of 1:3. Data on agro-morphological parameters yield and yield attributing traits were recorded during the time of harvesting and analyzed using MSTATC software.

\section{Result and discussion}

General observation of the research results showed that the crop yield increases when urine is applied in split and efficacy of urine increases with the supplement dose of phosphorus (P) and potash (K) from chemical fertilizer to increase yield of different crops as compared to urine applied in single dose at the time of planting. However, there is no significant difference in crop yield with different time of urine application. But significant difference was observed for chemical fertilizer only (treatment 2) in potato 2004 and onion 2005 (Table 2). This might be due to handling losses of urine collection and application. In case of short duration crops like potato, 2 splits urine application along with $\mathrm{P}$ and $\mathrm{K}$ gave the comparable result with that of chemical fertilizer. Similarly other crops like rice, wheat, onion and radish requires 3 splits application of urine dose in supplement of $\mathrm{P}$ and $\mathrm{K}$.

Table 2. Effect of human urine on crop yield (t/ha) at Lalitpur, 2004-06

\begin{tabular}{|c|c|c|c|c|c|c|c|c|c|c|}
\hline \multirow{2}{*}{ Crop } & \multirow{2}{*}{ Year } & \multicolumn{6}{|c|}{ Treatment } & \multirow{2}{*}{ F test } & \multirow{2}{*}{$\begin{array}{c}\text { LSD } \\
\mathbf{P}<\mathbf{0 . 0 5}\end{array}$} & \multirow{2}{*}{$\begin{array}{c}\text { CV } \\
\%\end{array}$} \\
\hline & & 1 & 2 & 3 & 4 & 5 & Mean & & & \\
\hline \multirow[t]{3}{*}{ Potato } & 2004 & 11.20 & 15.80 & 11.60 & 11.20 & 12.80 & 12.43 & $*$ & 2.70 & 14.20 \\
\hline & 2005 & 15.10 & 18.10 & 16.80 & 17.00 & 17.40 & 17.10 & ns & - & 17.36 \\
\hline & Mean & 13.10 & 17.00 & 14.20 & 14.50 & 15.10 & 14.67 & - & - & - \\
\hline \multirow[t]{2}{*}{ Rice } & 2004 & 6.68 & 6.72 & 5.69 & 6.35 & 6.04 & 6.24 & $\mathrm{~ns}$ & - & 9.21 \\
\hline & 2005 & 7.99 & 7.54 & 8.01 & 7.07 & 7.45 & 7.59 & $\mathrm{~ns}$ & - & 10.45 \\
\hline
\end{tabular}


Agronomy Journal of Nepal (Agron JN) Vol. 2: 2011

\begin{tabular}{|c|c|c|c|c|c|c|c|c|c|c|}
\hline \multirow{2}{*}{ Crop } & \multirow{2}{*}{ Year } & \multicolumn{6}{|c|}{ Treatment } & \multirow{2}{*}{ F test } & \multirow{2}{*}{$\begin{array}{c}\text { LSD } \\
\mathbf{P}<\mathbf{0 . 0 5}\end{array}$} & \multirow{2}{*}{$\begin{array}{c}\text { CV } \\
\%\end{array}$} \\
\hline & & 1 & 2 & 3 & 4 & 5 & Mean & & & \\
\hline & Mean & 7.34 & 7.13 & 6.85 & 6.71 & 6.75 & 6.92 & - & - & - \\
\hline \multirow[t]{3}{*}{ Wheat } & 2005 & 1.86 & 2.55 & 2.46 & 2.50 & 2.56 & 2.39 & $\mathrm{~ns}$ & - & 28.05 \\
\hline & 2006 & 1.23 & 1.45 & 1.21 & 1.20 & 1.06 & 1.23 & $\mathrm{~ns}$ & - & 2.45 \\
\hline & Mean & 1.55 & 2.00 & 1.83 & 1.85 & 1.81 & 1.81 & - & - & - \\
\hline \multirow[t]{3}{*}{ Radish } & 2004 & 64.24 & 70.55 & 51.31 & 57.62 & 64.84 & 61.70 & ns & - & 18.11 \\
\hline & 2005 & 66.61 & 82.10 & 70.53 & 63.43 & 65.76 & 69.70 & ns & - & 15.23 \\
\hline & Mean & 65.43 & 76.33 & 60.92 & 60.53 & 65.30 & 65.70 & - & - & - \\
\hline Onion & 2004 & 46.48 & 51.50 & 50.61 & 45.23 & 46.59 & 48.08 & $*$ & 4.89 & 6.61 \\
\hline
\end{tabular}

Note: $1=$ Urine only at 3 split, $2=$ Chemical only, $3=$ Urine at basal $+\mathrm{PK}, 4=$ Urine at 2 split $+\mathrm{PK}, 5=$ Urine at 3 split $+\mathrm{PK}, *=$ Significant at $\mathrm{P}<0.05$ and $\mathrm{ns}=$ not significant.

In general, the effect of nutrient applied through the urine was lower than nutrient applied through chemical fertilizer. This might have resulted in the loss of nitrogen in the form of ammonia gas during handling and application in the field resulted in lower crop yield in urine-applied plots. Therefore, it can be suggested that the urine application can be as much effective as chemical fertilizer for crop production if losses during handling and application could be minimized.

\section{Conclusion and recommendation}

The study reveals that urine could act as effective as a chemical fertilizer and can be used as an efficient source of plant nutrients. The efficacy of urine increases in association with $\mathrm{P}$ and $\mathrm{K}$ from chemical fertilizer. Hence, it can be concluded that any crops can be grown using urine as a fertilizer without significant reduction in the yield if nutrient losses during handling could be minimized. But urine content lower $\mathrm{P}$ and $\mathrm{K}$ need to be supplemented either with chemical fertilizer or by compost for better crop yield.

Joint effort by different formal and informal development agencies would help for quick dissemination and adoption of ecological sanitation (ECOSAN) toilets in remote hilly districts. ECOSAN toilets help in safer sanitation and recycling of human waste as fertilizer which ultimately help to reduce food crisis to some extent by increase crop yield.

\section{References}

Esrey, S plus et al. 1998. Ecological Sanitation, Sida, Stockholm.

Hoglund, C. 2000. Variation of chemical and microbial parameters in collection and storage tanks for source separated human urine. Journal of Environmental Science and Health part A; Environmental Science and Engineering 35: 1463-1475. 
Joshi U. 2000. Ensuring food safety in the Kathmandu valley. In ENPHO a decade $10^{\text {th }}$ Anniversary Souvenir. pp 34-36.

MoAC (Ministry of Agriculture and Cooperative). 2009. Agriculture dairy. GoN, MoAC, Agriculture Information and Communication Centre, Hariharbhawan, Lalitpur.

Vinneras B, H Jonson. 2002. Fecal separation for nutrient management-evaluation of different separation techniques. In Possibilities for sustainable nutrient recycling by fecal separation combined with urine diversion pp 1-17.

Vinneras B, H Jonson, E Salomon, AR Stinzing. 2004. Tentative guidelines for agricultural use of urine and feces in: ECOSAN-closing the loop. In Proceeding of the 2nd International symposium on ecological sanitation, incorporating the 1st IWA specialist group conference on sustainable sanitation, GTZ, Germany: pp 101-108. 